screen 100 urines a day. This would make it feasible to test children in large numbers in their schools.

It is hoped that this study shows once more how advantageous it is for a clinician, whether in hospital or in general practice, to examine the urine under a microscope.

\section{Summary}

Eighty-two children who had been treated for acute pyelonephritis during the previous 13 years were reviewed as outpatients.

Twenty children (19 girls) were found to have persistent urinary infection; 11 of these were symptomless and appeared to be in excellent health. Cysto-urethrography showed the presence of vesico-ureteric reflux in half of them.

Independent but parallel white-cell counts were done on 97 specimens of urine in order to compare the value of a standardized wet-film examination in out-patients with the use of a Neubauer counting chamber in the laboratory. Significant pyuria was present in 27 specimens and was detected by the wet-film method in 26 .

The intermittency both of pyuria and bacteriuria (as judged by simple culture) in the urine of children known to have persistent infection was confirmed, and emphasizes the need for more than one examination.

The commonness of this infection, its latency, its possibly serious consequences, and the unsatisfactory results of its treatment present a challenge to paediatricians and others concerned with child health.

We are much indebted for help in this study and in the preparation of this paper to Miss P. Homan, Dr. P. Freeman, Dr. M. Israelski, and the staff of the Radiography Department, Warwick Hospital ; Dr. A. P. Prior and the staff of the Group Pathological
Laboratory ; and Sisters B. E. Morgan and M. D. Lucas, of the Children's Ward, Warwick Hospital.

\section{APPENDIX}

Area of microscope field using $\frac{1}{6}$ th objective and $\times 10$ eyepiece (diameter of field measured with Neubauer counting chamber ruling $=0.4 \mathrm{~mm}$ )

$$
=\pi \mathrm{r}^{2}=3.14 \times(0.2)^{2}=0.13 \text { sq. } \mathrm{mm} \text {. }
$$

Volume of urine beneath coverslip $=0.1 \mathrm{ml} .=100 \mathrm{c} . \mathrm{mm}$

Area of coverslip used $=22 \mathrm{~mm} . \times 26 \mathrm{~mm} .=572 \mathrm{sq}$. $\mathrm{mm}$.

So depth of urine film on slide $=100 \div 572 \mathrm{~mm} .=0.18 \mathrm{~mm}$.

Therefore volume of urine in each field $=0.13 \times 0.18$ c.mm. $=0.025 \mathrm{c} . \mathrm{mm}$. approx.

Hence number of fields per c.mm. $=1 \div 0.025=40$.

The calculations are approximate, as the method is imprecise, but the sum can be adapted to different objectives and sizes of coverslip. Thus it is easy to find roughly the number of high-power fields that must be examined under any specified conditions in order to search $1 \mathrm{c} . \mathrm{mm}$. of urine.

\section{REFERENCES}

Deluca, F. G., Fisher, J. H., and Swenson, O. (1963). New Engl. F. Med., 268, 75

Drillien; C. M. (1961). Arch. Dis. Childh., 36, 515.

Gross, R. E., Randolph, J., and Wise, H. M. (1963). New Engl. F. Med., 268, 5

Guttmann, D., and Stokes, E. J. (1963). Brit. med. 7., 1, 1384.

Kass, E. H. (1960). In The Biology of Pyelonephritis, edited by E. L. Quinn and E. H. Kass. Churchill, London.

Kleeman C. R. Hewitt, W. L., and Guze, L. B. (1960). Medicine (Balitimore), 39, 3.

Kunin, C. M., Zacha, E., and Paquin, A. J. (1962). New Engl. f. Med., 266, 1287.

Lancet, $1962,2,598$

$1963,1,148$.

Little, P. J. (1962). Lancet, 1, 1149.

Macaulay, D., and Sutton, R. N. P. (1957). Ibid., 2, 1318.

Rosenheim, M. L. (1963). Brit. med. f., 1, 1433.

Smallpeice, V. (1958). Lancet, 1, 103.

Stansfeld, J. M. (1962). Arch. Dis. Childh., 37, 257.

Straffon, R. A., and Engel, W. J. (1960). f. Amer. med. Ass., 174, 1377

Straffon, R. A., and Engel, W. J. (1960). F. Amer. med. Ass., 174, 1377.
Williams, D. J., and Sturdy, D. E. (1961). Arch. Dis. Childh., 36, 130.

\title{
Urine in Acute and Chronic Renal Failure
}

\author{
M. H. ROSCOE,* PH.D., M.B., CH.B.
}

Brit. med. F., 1964, 1, 1084-1087

Patients with anuria or oliguria often have no previous history of renal disease and nothing to indicate whether they are suffering from an acute and potentially reversible condition or from the final stages of a chronic condition. Attempts have therefore been made in the past, and are repeated here, to see whether when some urine is passed it differs in composition in the acute and chronic diseases.

The chief characteristic investigated was the osmolality, a measure of solute concentration. This was found to be low in both conditions and varied little, so that solute and water output changed together. Some implications of this in the management of acute failure are here considered.

\section{Patients and Methods}

The 10 patients with acute failure are shown in Table I. In eight cases failure was associated with accidents of pregnancy.

^ Department of Medicine, University of Manchester.
The case of phenindione sensitivity has been described in detail elsewhere (Baker and Williams, 1963). In the anuric and oliguric stages the fluid intake was limited to the previous day's loss in urine or vomit plus $400 \mathrm{ml}$., some of this being in the form of sucrose or glucose solution to provide calories. When an adequate urine volume was reached and the blood urea started to fall the diet was increased and free fluid intake allowed. In all cases 24-hour urines were collected.

The eight cases of chronic failure were all in the terminal stages of hypertensive renal failure of varying aetiology. They were given a low-protein diet and free fluid intake. In some cases sodium deficiency was treated by intravenous therapy. Twenty-four-hour urines were collected, except in Cases C2, C3, and C6, where the samples were consecutive one-hour ones.

Osmolalities were estimated by the freezing-point depression, using a Fiske osmometer or calculated from the following formulae:

Urine osmolality $=2\left(\mathrm{Na}++\mathrm{K}++\mathrm{NH}_{4}+\right)+$ urea

Plasma osmolality $=2(\mathrm{Na}++\mathrm{K}+)+$ urea -8 
Eight is deducted from the calculated figure for plasma to allow for the reduced osmotic activity of the ions in solution. The variable composition of urine does not allow such a correction (Roscoe, 1960). $\mathrm{Na}^{+}$and $\mathrm{K}+$ were estimated with a flame photometer and urea and $\mathrm{NH}_{4}{ }^{+}$with an autoanalyser.

TABLE I.-Patients With Acute Renal Failure

\begin{tabular}{l|c|c|c|c|} 
Case & $\begin{array}{c}\text { Age } \\
\text { and } \\
\text { Sex }\end{array}$ & Diagnosis and Aetiology & Biopsy & $\begin{array}{l}\text { Days from Onset of Anuria } \\
\begin{array}{c}\text { To Urinary } \\
\text { Vol. of } \\
200 \text { ml./day }\end{array}\end{array} \mid$ To Dialysis \\
\hline
\end{tabular}

A1 $\mid$\begin{tabular}{ll|l|l|l}
27 & Acute Cortical Necrosis \\
& F I Post-partum haemorrhage $|+|$ & 10 & $8,15,29$
\end{tabular}

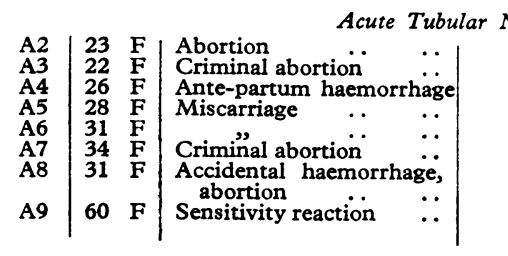

Acute Interstitial Nephritis A10 $47 \mathrm{M} \mid$ Phenindione sensitivity

\begin{tabular}{c|c}
0 & \\
0 & 1 \\
0 & 1 \\
0 & 15 \\
+ & 17 \\
+ & 20 \\
0 & 22 \\
+ & 20
\end{tabular}

12

plasma, in three isotonic, and in one slightly hypertonic. In two cases osmolality was not estimated in the early samples. Hypotonicity is seen both after dialysis and without dialysis. Low urine/plasma urea ratios are seen. Urinary sodium concentrations are seen to be variable and plasma sodium concentrations initially low.

Daily values for osmolalities and urea concentrations in urine and plasma are shown for two patients in Fig. 1. In Case A8, with acute tubular necrosis, urine osmolality increased, largely as a result of rising urinary urea, and reached that of serum after 10 days. In Cases A3 and A9 (not shown) isotonicity was attained, again by an increase in urinary urea, after four and five days respectively. In Case $\mathrm{A} 1$, with acute cortical necrosis, isotonicity was reached only after 17 days and there was little increase in urinary urea, but after the first six days the urine volume increased markedly, so that the urea excretion rose. This increase in volume is the result of increased fluid intake and not of previous overhydration, a gain in weight occurring over this period.

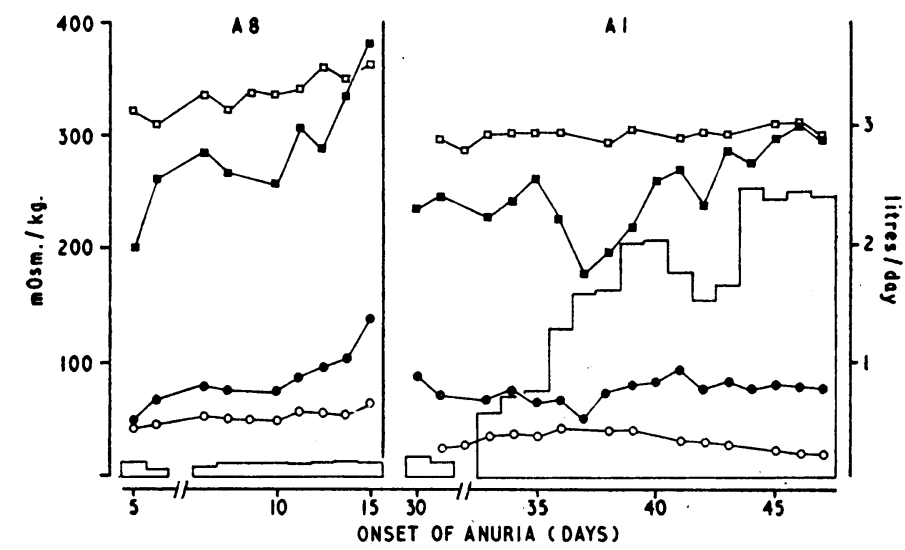

Fig. 1.-Urine volumes and urine and blood concentrations of osmols and urea in a patient with acute tubular necrosis (Case A 8) and one with acute cortical necrosis (Case A 1). $\mathrm{O}=$ Blood urea. $\quad=$ =Urine urea. $\square=$ Serum osmolality. $\square=$ Urine osmolality.

\section{Later Stages (Table III)}

During this stage the urine volume increases, and is the most reliable sign of improvement, but the daily volume with which recovery as shown by a falling blood urea occurs is very variable. As rapid a fall in blood urea was seen in one patient seldom passing more than 1 litre a day as in others passing 2 litres or more. Volumes exceeding 3.5 litres a day were not seen in these patients.
The first daily urine volumes recorded were $200 \mathrm{ml}$. or less in all except two cases, increasing to $500 \mathrm{ml}$. or more in 3 to

17 days. In four cases the samples were at first hypotonic to

The patients were admitted to hospital after varying periods of anuria or oliguria. Anuria continued in some, but eventually urine was passed by all in increasing amounts. The daily volume in the early stages did not exceed 1 litre and the blood urea continued to rise, except when lowered by dialysis.

TABLE II.-Urine and Plasma Concentrations of Osmols, Urea, and Sodium in Severe Chronic Renal Failure and the Early Stages of Recovery from Acute Renal. Failure

\begin{tabular}{|c|c|c|c|c|c|c|c|c|c|}
\hline \multirow{2}{*}{$\begin{array}{l}\text { Case } \\
\text { No. }\end{array}$} & \multirow{2}{*}{$\begin{array}{l}\text { No. of } \\
\text { Samples }\end{array}$} & \multirow{2}{*}{$\begin{array}{l}\text { Days from } \\
\text { Onset of } \\
\text { Anuria }\end{array}$} & \multirow{2}{*}{$\begin{array}{l}\text { Creatinine } \\
\text { Clearance } \\
\text { ml./min. }\end{array}$} & \multirow{2}{*}{$\begin{array}{l}\text { Urine Volume } \\
\text { ml./24 hr. } \\
\text { Mean or Range }\end{array}$} & \multicolumn{2}{|c|}{ Osmolality mOsm. $/ \mathrm{kg}$. Range } & \multirow{2}{*}{$\begin{array}{l}\text { U./P. } \\
\text { Urea } \\
\text { Lowest }\end{array}$} & \multicolumn{2}{|c|}{$\mathrm{Na}^{+} \mathrm{mEq} / \mathrm{l}$. Range } \\
\hline & & & & & Urine & Plasma & & Urine & Plasma \\
\hline \multicolumn{10}{|c|}{ Chronic Renal Failure } \\
\hline $\begin{array}{l}\text { C1 } \\
\text { C2 } \\
\text { C3 } \\
\text { C4 } \\
\text { C5 } \\
\text { C6 } \\
\text { C7 } \\
\text { C8 }\end{array}$ & $\begin{array}{r}7 \\
3 \\
3 \\
9 \\
3 \\
4 \\
3 \\
15\end{array}$ & & $\begin{array}{l}9 \cdot 5 \\
6 \\
6 \\
5 \cdot 5 \\
2 \cdot 5 \\
1 \cdot 5 \\
1 \cdot 5 \\
2-1\end{array}$ & $\begin{array}{r}1,230 \\
1,340 \\
1,790 \\
1,480 \\
1,700 \\
985 \\
670 \\
700\end{array}$ & $\begin{array}{c}(170-250) \\
(250-280) \\
(315-325) \\
195-240 \\
(185-225) \\
260-305 \\
(210-215) \\
(195-270)\end{array}$ & $\begin{array}{c}(280) \\
(308) \\
(333) \\
308 \\
(315) \\
305 \\
(277) \\
(295-301)\end{array}$ & $\begin{array}{l}2.7 \\
3.5 \\
2.8 \\
1.4 \\
1.4 \\
2.5 \\
2.5 \\
2.5\end{array}$ & $\begin{array}{r}32-65 \\
32-39 \\
36-56 \\
39-55 \\
43-49 \\
69-84 \\
11-15 \\
4-20\end{array}$ & $\begin{array}{c}131,134 \\
139 \\
145 \\
129-140 \\
138 \\
136 \\
117 \\
121-129\end{array}$ \\
\hline $\begin{array}{l}\text { A1 } \\
\text { A2 } \\
\text { A3 } \\
\text { A5 } \\
\text { A6 } \\
\text { A7 } \\
\text { A8 } \\
\text { A9 } \\
\text { A10 }\end{array}$ & $\begin{array}{r}5 \\
3 \\
4 \\
3 \\
11 \\
5 \\
10 \\
5 \\
4\end{array}$ & $\begin{array}{r}29-35 \\
14-16 \\
11-15 \\
13-15 \\
16-26 \\
29-33 \\
5-14 \\
12-16 \\
13-17\end{array}$ & $\begin{array}{l}= \\
= \\
= \\
=\end{array}$ & $\begin{array}{r}170-740 \\
630-880 \\
200-450 \\
145-465 \\
20-920 \\
200-500 \\
50-125 \\
30-135 \\
510-910\end{array}$ & $\begin{array}{c}\text { e Renal Fail } \\
(225-260) \\
310-350 \\
165-295 \\
300-310 \\
310-340 \\
195-330 \\
200-300 \\
350-365\end{array}$ & $\begin{array}{l}(292-296) \\
(313-333) \\
(287-301) \\
(303-311) \\
(323-371) \\
(328-313) \\
(306-355) \\
(307-344) \\
(332-294)\end{array}$ & $\begin{array}{l}1 \cdot 85 \\
2 \cdot 6 \\
2 \cdot 05 \\
2 \cdot 5 \\
2 \cdot 15 \\
2 \cdot 35 \\
1 \cdot 2 \\
1 \cdot 15 \\
2 \cdot 4\end{array}$ & $\begin{array}{l}32-56 \\
69-92 \\
24-31 \\
45-87 \\
22-60 \\
45-67 \\
48-78 \\
15-29 \\
53-83\end{array}$ & $\begin{array}{l}127-133 \\
137-143 \\
127-136 \\
133-136 \\
130-150 \\
131-140 \\
130-150 \\
130-143 \\
130-136\end{array}$ \\
\hline
\end{tabular}


TABLE III.-Blood Ureas, Urine Volumes, and Osmolar Concentrations in Patients Recovering from Acute Renal Failure

\begin{tabular}{|c|c|c|c|c|c|c|c|c|c|c|}
\hline \multirow{2}{*}{$\begin{array}{l}\text { Case } \\
\text { No. }\end{array}$} & \multirow{2}{*}{$\begin{array}{l}\text { No. of } \\
\text { Samples }\end{array}$} & \multirow{2}{*}{$\begin{array}{c}\text { Days from } \\
\text { Onset } \\
\text { of } \\
\text { Anuria }\end{array}$} & \multicolumn{2}{|c|}{$\begin{array}{l}\text { Blood Urea } \\
\text { mg./100 ml. }\end{array}$} & \multicolumn{2}{|c|}{$\begin{array}{l}\text { Urine Volume } \\
\text { ml./day }\end{array}$} & \multicolumn{2}{|c|}{$\begin{array}{l}\text { Urine Osmolality } \\
\text { mOsm. } / \mathrm{kg} .\end{array}$} & \multicolumn{2}{|c|}{$\begin{array}{l}\text { Correlation between } \\
\text { Urine Osm. and Vol. }\end{array}$} \\
\hline & & & First & Last & Range & Mean & Mean & S.D. & $\mathbf{r}$ & $\mathbf{P}$ \\
\hline $\begin{array}{l}\text { A1 } \\
\text { A2 } \\
\text { A3 } \\
\text { A4 } \\
\text { A5 } \\
\text { A6 }\end{array}$ & $\begin{array}{r}11 \\
9 \\
9 \\
9 \\
15 \\
4 \\
8\end{array}$ & $\begin{array}{l}46-56 \\
16-25 \\
16-24 \\
17-25 \\
16-31 \\
29-32 \\
33-41\end{array}$ & $\begin{array}{l}136 \\
260 \\
207 \\
285 \\
255 \\
330 \\
175\end{array}$ & $\begin{array}{r}68 \\
61 \\
40 \\
36 \\
30 \\
175 \\
58\end{array}$ & $\begin{array}{r}1,930-3,340 \\
650-2,020 \\
1,090-2,900 \\
850-1,770 \\
980-3,380 \\
860-1,560 \\
1,180-2,380\end{array}$ & $\begin{array}{l}2,710 \\
1,320 \\
1,810 \\
1,210 \\
2,275 \\
1,180 \\
1,665\end{array}$ & $\begin{array}{l}274 \\
355 \\
195 \\
355 \\
220 \\
340 \\
230\end{array}$ & $\begin{array}{r}30 \\
16 \\
41 \\
24 \\
38 \\
5 \\
31\end{array}$ & $\begin{array}{l}-0.715 \\
+0.005 \\
-0.83 \\
+0.025 \\
-0.61 \\
-\overline{0.54}\end{array}$ & $\begin{array}{c}0.02 \\
>0.1 \\
0.01 \\
>0.1 \\
0.02 \\
>0.1\end{array}$ \\
\hline A7 \{ & $\begin{array}{l}21 \\
15\end{array}$ & $\begin{array}{l}29-49 \\
50-64\end{array}$ & $\begin{array}{l}320 \\
180\end{array}$ & $\begin{array}{r}180 \\
37\end{array}$ & $\begin{array}{r}200-1,340 \\
1,080-3,370\end{array}$ & $\begin{array}{l}685 \\
2,450\end{array}$ & $\begin{array}{l}320 \\
170\end{array}$ & $\begin{array}{l}36 \\
27\end{array}$ & $\begin{array}{l}+0.04 \\
-0.68\end{array}$ & $\begin{array}{l}>0.1 \\
0.01\end{array}$ \\
\hline $\begin{array}{l}\text { A8 } \\
\text { A9 } \\
\text { A10 }\end{array}$ & $\begin{array}{l}13 \\
13 \\
21 \\
26\end{array}$ & $\begin{array}{l}15-33 \\
34-47 \\
23-43 \\
13-38\end{array}$ & $\begin{array}{l}380 \\
270 \\
325 \\
350\end{array}$ & $\begin{array}{r}270 \\
90 \\
45 \\
27\end{array}$ & $\begin{array}{l}110-1,750 \\
810-1,580 \\
570-1,560 \\
510-3,210\end{array}$ & $\begin{array}{r}900 \\
1,190 \\
945 \\
1,855\end{array}$ & $\begin{array}{l}335 \\
250 \\
355 \\
390\end{array}$ & $\begin{array}{l}19 \\
21 \\
28 \\
40\end{array}$ & $\begin{array}{l}-0.08 \\
-0.69 \\
-0.34 \\
+0.22\end{array}$ & $\begin{array}{l}>0.1 \\
0.01 \\
>0.1 \\
>0.1\end{array}$ \\
\hline
\end{tabular}

The osmolality of the urine, in most patients, initially does not alter appreciably with increasing flow but remains at the slightly hypertonic level reached at the end of the oliguric period. This constant osmolality with a changing volume means that solute and water output vary together. The solute excretion increases, firstly, to remove the retained urea, and, secondly, to deal with metabolites from the increased diet taken at this time. An example of this is shown in Fig. 2. The increased water excretion could not be considered a removal of oedema, since there was a concurrent gain in weight. The diuresis thus appears to be due to an increased solute excretion carrying with it large volumes of water. This suggests inability to concentrate the urine. Concentration tests are not available for patients with rising urine volumes, but in two cases (Nos. A6 and A8) who had recovered to the point of having normal blood ureas, the maximal values of urine osmolality after 1 unit of aqueous "pitressin" intramuscularly were 340 and 395 mOsm./kg. respectively, as compared with 800-900 mOsm./ $\mathrm{kg}$. reached by normal subjects.

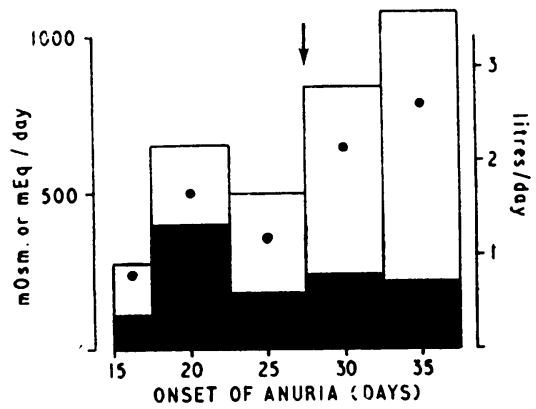

FIG. 2.- Solute and water excretion in Case A 10. The values are means of threeor five-day periods. Electrolytes, $\square$. Urea, Water, At the arrow the diet was increased and extra $\mathrm{NaCl}$ given.

In some cases the increasing urine volume is associated with decreasing osmolality (Table III, negative $r$ ), the correlation being significant in $5(P=0.02$ or less). Two of these, $A 3$ and A5, were mild cases, and in the others the dilution occurred after a previous period of rising osmolality or constant hypertonicity. This diuresis is not consistently associated with increasing solute output and may be regarded as a water diuresis due to increasing fluid intake. Osmolalities of less than 160 $\mathrm{mOsm} . / \mathrm{kg}$. were not seen, but a test of diluting capacity was carried out only in the patient with acute interstitial nephritis (Case A10), and he showed severe limitation of this function which lasted for at least 10 weeks.

\section{Discussion}

In this work hypotonic urine was found in association with severe renal failure both in the oliguric stage of acute tubular necrosis and in terminal renal failure. In the acute forms of failure the fluid intake had been so limited that maximal concentration could be expected.

In chronic renal failure it has been thought that isotonic urine is usually passed, but this opinion is based on specific gravity estimations which are very inexact indications of osmolality. It is known that the range of osmolality obtained in concentration and dilution tests decreases as the filtration rate falls, and it is assumed that finally there is isosthenuria. Kleeman et al. (1961), however, working on this assumption, found a greater depression of concentration than of dilution, and 4 out of their 22 cases had maximal values of urine osmo lality less than the values of plasma osmolality, while hypotonic urines were always obtained. In fact, the maximal and minimal values which they record show very similar decreases and increases respectively as filtration rate falls, but tending towards a hypotonic level of about $250 \mathrm{mOsm} . / \mathrm{kg}$. This suggests that this is the osmolality with a normal fluid intake.

In acute failure records of osmolalities are sparse, but in one case recorded by Bull (1956) the early urines were hypotonic, increasing to isotonicity with improvement. In the later stages concentration tests have shown considerable reduction in this function (Baldwin et al., 1955), but dilution power does not seem to have been directly investigated.

The limited previous reports are therefore quite consistent with the present finding that in severe failure the urine tends to be hypotonic, not isotonic, and some theories of urine formation should be reconsidered with this in mind.

The limited range of osmolality previously recorded for chronic renal failure is seen here in the recovering acute failures. Even under the stress of a low fluid intake the urine osmolality is never very high, and, conversely, when fluid intake is free only moderate hypotonicity is found. The attainment of a normal range of osmolalities appears to be slow.

Since concentration of urine is limited the increased volumes formed as solute excretion increases are obligatory, this being in fact an osmotic diuresis. This has already been suggested by Swann and Merrill (1953). Bull (1956) also considered the very large diuresis, seen when the accepted treatment was a fluid intake of the previous day's output plus 1 litre, to be osmotic, due to the excretion of the retained urea. Since urea is now eliminated as rapidly, with lower fluid intakes and outputs, it looks as if formerly excess water was also being removed. If this were true the urines would be hypotonic, and in fact this can sometimes be calculated from the data. In a case recorded by Iseri et al. (1952) the urine volume rose to 8 litres a day and had an osmolality of $155 \mathrm{mOsm} . / \mathrm{kg}$.

So high an osmolality at this high volume indicates failure to dilute; this may have been responsible for the electrolyte deficiency which often developed in overhydrated patients. In the present series no excessive excretion of electrolytes occurred with the moderate diuresis, though low serum sodiums and signs of sodium deficiency were sometimes seen in the pre-diuresis stage, when no sodium was taken by mouth and losses In vomit and diarrhoea occurred. 
It should be emphasized that a massive diuresis is not an obligatory stage in recovery, that when it occurs it is due to previous overhydration and should not therefore be treated by fluid replacement. The emphasis is necessary because numerous recent publications still advise this treatment, which can only perpetuate the overhydration and cause electrolyte loss.

The determining factor in deciding the nature of a diuresis is the urine osmolality. If this is hypotonic it is one of water and an increasing intake is not desirable. If it is isotonic or hypertonic it is one of solutes and an increased fluid intake may be encouraged. In practice it is generally safe at this stage to allow a free intake; but some patients then, as a reaction to prolonged deprivation, drink excessively (although one patient was afraid to drink at all in case she still could not pass it).

In this work there is no consistent difference between the urines of cases with chronic failure or acute failure which could help in deciding between the two conditions. The absence of any difference has already been emphasized by Franklin and Merrill (1960), but clinicians continue to seek for one. Prerenal conditions, such as a marked reduction in food and water intake, may also produce oliguria and a relatively dilute urine. Joekes et al. (1957) consider that such urines can be distinguished by their low sodium concentration; but this is uncertain, since similar low concentrations are seen here in acute failure.

\section{Summary}

The concentration of urea, electrolytes, and total osmols was studied in the urines of patients with acute and chronic renal failure. No differences which could be used in distinguishing the two conditions were found.

Patients with chronic failure, when neither dehydrated nor overhydrated, passed urine which was hypotonic to or isotonic with plasma and never hypertonic. Those with acute failure also often passed hypotonic urine at first, the osmolality increasing to that of plasma or slightly more with improvement. This, since the fluid intake was strictly limited, shows an inability to concentrate, which resulted in an increase in urine volume as solute excretion increased. Improvement in concentrating power was slow, but recovery, as shown by excretion of retained urea, occurred satisfactorily with these dilute urines, although the daily urine volumes were often only about 1.5 litres and did not exceed 3.5 litres. High volumes suggest previous or concurrent overhydration, which can be confirmed by the finding of hypotonic urine. The fluid intake under these circumstances should be less than the output.

My thanks are due to Professor D. A. K. Black, whose patients were investigated.

\section{REFERENCES}

Baker, S. B. de C., and Williams, R. T. (1963). Brit. med. 7., 1, 1655. Baldwin D. Se Berman H. J Heinemann, H. O., and Smith, H. W. (1955). \%. clin. Invest., 34, 800.

Bull, G. M. (1956). In Modern Views on Secretion of Urine, edited by F. R. Winton, p. 256. Churchill, London.

Franklin, S. S., and Merrill, J. P. (1960). New Engl. F. Med., 262, 711, 761.

Iseri, L. T., Batchelor, T. M., Boyle, A. J., and Myers, G. B. (1952). Arch. intern. Med., 89, 188.

Joekes, A. M., Mowbray, J. F., and Dormandy, K. (1957). Lancet, 2, 864.

Kleeman, C. R., Adams, D. A., and Maxwell, M. H. (1961). 7. Lab. clin. Med., 58, 169 .

Roscoe, M. H. (1960). f. clin. Path., 13, 514.

Swann, R. C., and Merrill, J. P. (1953). Medicine (Baltimore), 32, 215.

\title{
Multiple Attacks of Aseptic Meningitis in the Same Individual
}

\author{
ERKKI KLEMOLA,* M.D.; KAISA LAPINLEIMU,* M.D.
}

Brit. med. F., 1964, 1, 1087-1090

Interest has recently been focused on patients suffering from multiple attacks of suppurative meningitis. In most of these cases it is possible to establish as the predisposing factor an earlier trauma which has left anatomical changes in the base of the skull that make it easier for bacteria to invade the central nervous system.

How common is it, then, for a person to have several attacks of aseptic meningitis or acute infectious encephalitis? So far as we have been able to establish, no reference has been made to the subject in the literature. Only recently have advances in virology made it possible to establish the viral aetiology and make a specific diagnosis in a considerable proportion of aseptic meningitides and encephalitides. Moreover, even in the cases in which virological studies do not yield a positive result, there are nowadays better chances of excluding with high probability other aetiological factors causing diseases of the central nervous system.

\section{Own Patients. Criteria for Aseptic Meningitis}

We have personally had an opportunity of examining and following four patients who have had the syndrome of aseptic meningitis two to four times-in all 11 times-during observation periods of $1 \frac{1}{2}$ to 11 years.
The signs and symptoms in all attacks fulfilled Arvid Wallgren's (1925) criteria for the diagnosis of aseptic meningitis: (1) acute onset with obvious signs and symptoms of meningeal involvement, (2) alteration of cerebrospinal fluid typical of meningitis, (3) absence of bacteria in cerebrospinal fluid, as demonstrated by appropriate direct or cultural techniques, (4) relatively short benign course of illness, (5) absence of local parameningeal infection (otitis, sinusitis, trauma, etc.), or a general disease which might present meningitis as a secondary manifestation.

Later authors have accepted Wallgren's criteria, but many have preferred other names-for example, viral meningitis and primary serous meningitis-for this syndrome. Since these terms also have their shortcomings aseptic meningitis is still used at least as a synonym. In addition to many viruses some other micro-organisms, especially leptospires, may cause the syndrome. However desirable an aetiological diagnosis in each individual case, for practical purpose the syndrome must have a designation, as the aetiology is often established only when the disease has already been cured, and often remains obscure. When, in addition to meningeal symptoms, there is anything suggestive of deeper involvement of the central nervous system

\footnotetext{
^ From Aurora Hospital and from the State Serum Institute, Helsinki, Finland.
} 